\title{
Sosiologiese eksegese van die Ou Testament geïllustreer aan die hand van Klaagliedere 3
}

I G P Gous

\begin{abstract}
Sociological exegesis of the Old Testament with particular reference to Lamentations 3
\end{abstract}

People experience change as a traumatic rearrangement of their life anchors. It is possible for religion to play a positive role in the process of coming to terms with change. The book of Lamentations is representative of an attempt to interpret the loss of anchors to the people of Jerusalem in 586 B.C. We can draw from their experiences only if we come to understand their world. Sociological exegesis provides invaluable insights to this effect. The history of sociological exegesis in the study of the Old Testament is briefly sketched, followed by an overview of the book of Lamentations, with particular reference to Lamentations 3, as an example of this type of exegesis.

Hansie en Grietjie was maar nog bogkinders toe hulle die waarde van bakens in 'n onbekende bos vermoed het. Was hul gort-bakentjies egter net meer standhoudend en betroubaar, het hul met veel minder moeite en ontbering hul geborgenheid herwin.

Tog, selfs al was hul krisishanteringsmeganisme onsuksesvol weens die eetbare aard van hul bakentjies, bly Hansie en Grietjie se basiese idee steeds geldig. Hul optrede is tekenend van 'n universeel-menslike behoefte. Diere kom in die wêreld met 'n detail-afdruk van die spesie se hanteringsbakens. Ons wat mense is, kom egter broos en ongekaart in die lewenslabirint aan. Om te oorleef, prent die ouers en ander samelewingsverbande 'n kaart by die nuweling in. Op 'n sekere ouderdom begin mens self die bakens wat vir jou die meeste sin maak, te kies en om daarvolgens jou eie paadjie te loop. En, soos met Hansie en Grietjie, het die keuse van bakens ' $n$ belangrike invloed op mense se lewenskwaliteit.

Die verlies van bakens is ' $n$ baie traumatiese gebeure. Gou voel jy jou 'n gevangene in ' $n$ heksehok, met al die potensiaal om jou lewe te verloor in die lewenskookpot. Dit is egter 'n feit van die lewe. Elkeen van ons kan daarop reken dat ons een of ander tyd vervaard en naarstigtelik in die donker gaan rondtas, omdat 'n baken se liggie uitgedoof het. Aan hierdie feit het die verhaal van Hansie en Grietjie sy bestaan te danke. Lank voor dit, het die boek Klaagliedere ontstaan omdat dit waarop mense gereken het, padgegee het. Die impak van die val van Jerusalem in $586 \mathrm{vC}$, waarop die boek Klaagliedere reageer, was nie so groot bloot omdat mense verowering deur 'n vyand en alles wat daarmee gepaard gaan, beleef het nie. Die grootste verlies was die feit dat hul sinsbakens vernietig is. Die land waarin hulle gewoon het, was God se beloofde geskenk aan hulle. Die stad was waar God in sy tempel gewoon het, en die koning was uit die stam van Dawid wat vir ewig as God se verteenwoordiger sou regeer. Met die verowering is hul land nie meer hul eie nie, die stad en tempel is verwoes, en hul koning in gevangeskap. Dit beteken ten diepste dat God self, as oprigter en waarborg van hierdie bakens, soek 
geraak het. Die Baken self het verdwyn. Die boek Klaagliedere is 'n poging om opnuut rigting aan te dui vir ontredderde, verdwaalde mense.

Aan dieselfde realiteit is hierdie artikel te wyte. Die realiteite onderliggend aan die boek Klaagliedere is nie so ver verwyder van die situasie in Suid-Afrika in die 1990's nie. Die geskiedenis van ons land is deurspek van mense wat hul bakens verloor het - grond, ondersteuningsgroepe, sinsisteme. Die verskil is gewoonlik net wie in 'n spesifieke stadium aan die verloorkant was of is. Daarom is dit so relevant om die dinamiek van die proses van die keuse van, reken op en verlies van bakens te kyk. Dit op sigself kan dalk ' $n$ anker in stormagtige tye bied.

Daar is gelukkig ook voorbeelde van mense wat hul opnuut kon oriënteer. 'n Mens kan jou ankers kies, ook in stormagtige tye. Niemand is uitgelewer aan sy of haar verlede nie. Vorige negatiewe ervarings hoef nie ' $n$ vonnis te wees wat hom oor jou toekoms voltrek nie. Dit verg egter 'n sekere ingesteldheid. Menswetenskaplikes én teoloë aanvaar vandag dat mense wat beheer en inisiatief neem in hul lewe, gelukkiger is as mense wat voel dat hulle beheer word. Eersgenoemde staan bekend as mense met ' $n$ interne lokus van kontrole, teenoor die ander met 'n eksteme lokus van kontrole. Die hanteringsmeganismes van eersgenoemde is heelwat beter as dié van laasgenoemde. Omdat hulle verantwoordelikheid vir hul lot aanvaar, vertoon hulle 'n aktiewe hanteringsoriëntasie, hoë inisiatief en realistiese doelwitstelling. Hulle doen goeie beplanning met in agneming van hindernisse en is bewus watter mate van inset nodig sal wees om die doel te bereik. Verder het hulle die vermoë om sukses te geniet, mislukkings te hanteer en uit beide te leer. Voor, in of dalk iewers elders rondom die wapad, brand daar tog 'n lig. Daarom wil ek in hierdie artikel kyk hoe dit kan gebeur. Aangesien ek dit hier vanuit geloofsperspektief benader, gaan ek aandag gee aan

* die rol van geloof,

* die proses van sosiologiese eksegese,

* die boek Klaagliedere as voorbeeld daarvan,

* en laastens enkele opmerkings oor ons situasie in Suider-Afrika vandag.

\section{Hoekom glo mense? - (sosiologies beskou)}

Sosiologies beskou, is daar heelwat verskil oor die doel en funksie van geloof. Volgens Tylor glo mense om die wêreld te verklaar, 'n tipe "proto-wetenskap". Volgens Frazer glo mense om daardeur die wêreld te beheer. Durkheim, RadcliffeBrown en Malinowski meen dit is om die samelewing in stand te hou, en in Marx se oë is dit om ekonomiese onderdrukking in stand te hou of daarvoor te vergoed. Freud beweer dit is om die onderdrukking van seksuele gevoelens in 'n samelewing waar dit onderdruk word in stand te hou, en Jung glo dit is om die kollektiewe onbewuste van 'n psigologies-onontwikkelde persoon onbewus vry te laat ${ }^{1}$.

Clifford Geertz ${ }^{2}$, 'n leidende sosio-kulturele antropoloog, meen egter daar is meer aan geloof as wat die voorafgaande teoretici vermoed. Volgens hom beantwoord godsdiens aan die mens se ingebore, onontbeerlike behoefte aan sin ingevolge waarvan die indiwidu sy ervarings kan interpreteer en waarvolgens hy sy optrede kan modelleer. Godsdiens is dus 'n kulturele sisteem wat 'n wêreldbeeld verskaf en goddelike sanksie aan die etos gee. Hiermee beweer hy nie dat dit al is wat godsdiens behels nie - inteendeel, hy beskou godsdiens as 'n te komplekse 
verskynsel om geheel en al of selfs grootliks sosiologies te verklaar. Hy konsentreer bloot op hierdie aspekte, en beskryf geloof soos volg:

Eerstens, godsdiens is 'n sisteem van simbole. Mense "vertaal" dit wat hulle dink, ervaar, begeer en glo in simbole. Simbole kan 'n objek wees, soos byvoorbeeld 'n kruis, 'n altaar, 'n kerkgebou of selfs 'n gemeente. Dit kan egter ook 'n handeling wees, byvoorbeeld die nagmaal of die doopritueel. Die simbool beliggaam dus ' $n$ idee of groep idees waarvan die betekenis bekend is aan die groep wat dit gebruik.

Tweedens skep godsdiens ' $n$ bepaalde stemming of lewensingesteldheid. Mense kyk na die werklikheid deur die bril van hulle simboolsisteem. Die wyses waarop mense gebeure ervaar of daarop reageer, hou hiermee verband. Hul wêreldbeeld bepaal dus wat hulle as gewens en ongewens, goed en sleg, reg en verkeerd beskou, en ook hoe hulle gaan voel en optree as hulle met 'n spesifieke situasie of keuse gekonfronteer word. Dit gaan om die persoon se lewenswaardes wat 'n rol speel in sy of haar reaksies en besluite.

Derdens rig godsdiens ' $n$ mens se lewe. Op grond van die plek wat jy in die werklikheid beklee of wat aan jou toegeken is, streef jy sekere doelwitte na en bou jy aan sekere projekte. Sommige gelowiges meen dit is hul taak om aan ander diens te lewer ongeag hulle eie behoeftes. Ander weer beskou eerlike, harde werk om eie doelwitte te bereik as 'n deug. Ons verwys na mense se lewensingesteldheid en gerigtheid as hulle etos.

Vierdens orden godsdiens die wêreld om jou. Omdat mense nie met 'n ingeboude padkaart gebore word nie, teken hulle een vir hulself. Wanneer hulle egter by 'n "ongekaarte" lewensarea te staan kom, of hulle kaart is ontoereikend om hulle toepaslike aanwysings te gee, ervaar mense angs. Orde, voorspelbaarheid en die vermoë om ervarings te kan interpreteer, is 'n voorwaarde vir die ervaring van lewensin. Daar is egter veral drie soorte ervaringe wat mense as "ongekaart" ervaar en beangs maak: onverklaarbare ervarings, ervarings van lyding en die ervaring dat 'n onverdiende lot hul toeval. Geloof moet antwoorde hierop bied.

Geloof voorsien dus ' $n$ spesifieke wêreldbeeld, 'n beeld van omvattende orde wat die gelowige in staat stel om lewensin te vind op sy of haar pad.

Laastens bevestig godsdiens sin ten spyte van lewensdruk. Dit gebeur deurdat godsdienstige byeenkomste by gelowiges 'n sekere siening van die werklikheid te weeg bring. Tydens so 'n byeenkoms word die "padkaart" van die lewe by gelowiges ingeprent, en kry hulle ook aanwysings oor hoe om daarvolgens te reis. Tydens die byeenkoms versmelt die wêreldbeeld en etos tot 'n eenheid. Die byeenkomste is dus sowel 'n weerspieëling van die werklikheid as 'n model daarvoor. Dit wil sê dat mens hieruit kan aflei wat die groep mense belangrik beskou en hoog ag, asook wat die ideaal is waarna hulle streef.

Om godsdiens te verstian soos dit so pas beskryf is, kan ons op 'n paar maniere heip. Ecrstens maak dit ons daarvan bewus dat geloof betrokke is by die sake van die dag. Godsdiens het te doen met mense se lewensvrae en ervarings. Daarom moet ons ingelig wees oor hoe en wat mense glo. Verder help dit ons om te besef dat godsdiens die sake van die dag beïnvloed, maar ook andersom. Hiervan moet alle gelowiges bewus wees, anders gaan hulle hulself en ander gelowiges misverstaan. Baie verskille en selfs hewige botsings tussen Christene wêreldwyd, maar ook in Suid-Afrika, kan daaraan toegeskryf word aan die feit dat mense hierdie wederkerige verhouding oor die hoof sien. Mense vergeet dat wie hulle is, 'n invloed uitoefen op hoe en wat hulle glo. Só gebeur dit dat mense meen húlle, en 
net hulle, is reg in hul beoordeling en optredes. Indien ons die Bybel goed wil verstaan, sal ons moet gaan kyk na die lewensvrae van 'n spesifieke tyd, watter invloed godsdiens daarop uitgeoefen het, maar ook watter invloed die vrae op die mense en die manier waarop hulle hul godsdiens bedryf het, uitgeoefen het.

Indien dit waar is van hoe geloof in ons tyd werk, geld dieselfde natuurlik vir die geloof van die mense van die Bybelse tye. Indien ons die Bybel reg wil verstaan, sal ons eksegetiese tegnieke met die sosiale werklikhede rekening moet hou. Soveel te meer omdat die tekste kom uit sosiale omstandighede totaal vreemd aan ons s'n.

SOSIOLOGIESE EKSEGESE

Tekste is per definisie vreemde entiteite wat ontsyfer moet word. Om 'n vaardige leser te wees, moet mens die taal magtig wees, literêre tegnieke kan herken, en literatuursoorte kan onderskei. Dit is egter net so onontbeerlik om ingelig te wees oor die konteks waarbinne 'n teks ontstaan het - wat die rede is waarom die outeurs die geskrif die lig laat sien het, wie hul lesers was, en wat vir hulle belangrik was. Boonop moet mens jou eie lewensteks kan lees: wie jyself is, wat jou sinsbakens is, wat jou konstellasie van gegewenhede is, en boonop met watter doel jy ander tekste lees. Eksegese is dus 'n reeks tegnieke waarop hierdie en ander vrae sistematies aan die orde gestel word. In hierdie proses maak teoloë gebruik van insigte uit ander wetenskappe om die vrae verantwoordelik en verantwoordbaar te stel - die literatuurwetenskappe, historiografie, argeologie, filosofie, sielkunde, ensovoorts.

Om verskeie goeie redes behoort ons ook dẹr die insigte van die sosiale wetenskappe geïnformeer te word. Taal is gewortel in ' $n$ sosiale sisteem ${ }^{3}$. Betekenis is nie inherent aan taal nie, maar word op grond van sosiale afspraak binne 'n sosiale sisteem toegeken. Daarom verskil 'n boorling se hantering van 'n taal van dié van 'n vreemdeling. Die verskil lê daarin dat die vreemdeling sy sosiale afspraak op die vreemde taal oordra en dit sy betekenisverwysing maak. Om dit te verhoed, is kennis van die sosiale afspraak wat aan taal sy betekenisraam verskaf 'n vereiste.

Verstaan vind plaas wanneer 'n leser met behulp van 'n teks 'n verwysingsraamwerk oproep, aan die hand waarvan hy betekenis toeken. Die leser mer sy sosiale sisteem tree dan in interaksie met dié van die teks. Dit bring mee dat verstaan wat nie anachronisties en etnosentristies wil wees nie, wat met ander woorde nie horisonvervangend of -verplasend wil optree nie, die sosiale sisteem van die teks moet deel of probeer konstrueer ${ }^{4}$. Die probleem van dekodering lê nie net op die linguïstiese vlak nie, maar ook op die vlak van verwysing na 'n sosiologiese betekenisraam 5 .

Die sosiale aard van tekste word dus tans al hoe meer erken en beklemtoon. Dit behels onder andere dat tekste as produkte van hul sosiale omgewing beskou word en dat die noue band tussen die teks en die konteks waarbinne dit ontstaan en waaruit dit voortkom, erken word. Die teks weerspieël dus onder andere sosiale behoeftes, groepsbelange, botsende ideologieë en die effek van groepsinteraksie ${ }^{6}$. Selfs op 'n meer basiese vlak word die siening dat waarheid en idees konteksgebonde en nie bowetydelik is nie, op Bybelse tekste en geloofsienings toegepas ${ }^{7}$. Herzog $\mathrm{II}^{8}$, weer, sluit aan by Gadamer se siening dat 'n teks 'n antwoord op 'n vraag is, en om die teks te verstaan moet die vraag geken word. 
Inagneming van die konteks is dus belangrik by interpretasie, want 'n teks sonder inhoud wat in geen konteks inpas nie, is bloot 'n onverstaanbare klankreeks'. Daarom moet ons verskeie tipes interpretasie erken, elk met 'n bestaansreg, legitimiteit, spesifieke fokuspunt en bypassende werkwyse wat kan wissel na gelang van die tipe kennis wat verlang word en die tipe literatuur onder beskouing 10. Van Luxemburg et al ${ }^{11}$ noem verskillende tipes interpretasie, waaronder interpretasies wat van 'n spesifieke vraagstelling soos 'n sosiologiese uitgaan, wat nie aanspraak maak op volledigheid nie, maar wel op geldigheid binne 'n deel van die terrein. Dit is daarom moontlik om die verhouding teks-oorspronklike konteks langs 'n weg te ondersoek wat reg sal laat geskied aan die sosiale aard van die vraagstelling. Hiervoor blyk die huidige gebruik van sosiologiese benaderingswyses geskik te wees.

2.1 'n Oorsig oor sosiologiese en sosiaal-antropologiese benaderingswyses tot teksinterpretasie in die Ou-Testamentiese wetenskap

Die Ou-Testamentiese wetenskap vertoon lank reeds ' $n$ interesse in sosiale aspekte. Dit het veral ter sprake gekom waar daar 'n bewussyn was van die afstand tussen die leser en die teks. Wilson 12 noem dat Hugo van St Victor (oorlede 1141) en die bekende Rasji reeds sosiale aspekte by teksinterpretasie in ag geneem het. Die historiese bewussyn wat in die Renaissance ontstaan het, het die historiese gaping tussen die teks en die latere leser skerp in die fokus geplaas, en die weg gebaan vir die inagneming van die konteks van tekste asook dié van die leser. Die aandag hieraan het egter hoofsaaklik bestaan uit die beskrywing van sosiale aspekte, en het nie werklik gepoog om 'n verklaring daarvoor te gee nie.

Die verklaring van sosiale realia met behulp van sosiologiese teorieë het sowat 'n eeu gelede in die Ou-Testamentiese wetenskap ingang gevind ${ }^{13}$. Max Weber was die eerste moderne sosioloog wat gepoog het om die oud-Israelitiese samelewing aan die hand van 'n sosiologiese teorie te ondersoek en te verklaar. Hierop het heelwat studies aan die hand van die sosiologie of antropologie oor die Israelitiese godsdiens gevolg, waaronder sommige studies van W Robertson Smith, Julius Wellhausen en Albrecht Alt. Op die terrein van die studie van Israelitiese literatuur, het Hermann Gunkel en Sigmund Mowinckel van die resultate van sosiologiese wetenskappe gebruik gemaak ${ }^{14}$.

Ná 'n bloeitydperk het die gebruik daarvan egter weer in onguns verval, waarskynlik as gevolg van die gebreke in die teorieë self 15 . Die beskrywing en inagneming van sosiale realia het egter steeds 'n plek beklee. So, byvoorbeeld, het A Alt en W F Albright onafhanklik van mekaar belangrike navorsingstrome geïnisieer wat hieraan aandag gegee het. Uit die Alt-stroom vloei Martin Noth se beskrywing van ou Israel as ' $n$ amfiktionie of twaalf-stamme-verbond voort, en uit die Albright-stroom George Mendenhall se siening dat die Israelitiese verbond 'n godsdienstige weergawe is van 'n politieke suserein-vasal-verdrag, asook die siening dat die Israelitiese inname van die land eintlik 'n opstand van plattelandse kleinboere (peasant revolt) was ${ }^{16}$.

Tans is daar hernude belangstelling in wat die sosiologiese wetenskappe tot die Bybelinterpretasie kan bydra. Die redes hiervoor is van uiteenlopende aard. Om mee te begin - eietydse sosiale vraagstukke het hernude belangstelling gewek in oplossings wat die sosiologie kan bied, ook onder Bybelnavorsers ${ }^{17}$. De Villiers ${ }^{18}$ wys op die herlewing van godsdienssosiologie en die groeiende belangstelling in die 
interaksie tussen teologiese uitsprake en die sosiale realiteite waarin en waaroor hulle gemaak word. Laasgenoemde interaksie blyk veral uit nuwere teksvondste. Wilson ${ }^{19}$ wys drie sake uit. Die belang van kennis van die konteks se vormende invloed op die taal, beelde, simbole en konsepte wat die outeur gebruik om te kommunikeer, word beklemtoon deur die probleme wat moderne lesers by die lees van die Ou Testament ondervind. Verder noem Wilson die invloed wat navorsers se onuitgesproke sienings van die samelewing van Israel in elk geval uitgeoefen het, en wat maar net sowel openlik gestel en getoets kan word. Laastens noem hy nuwe ontwikkelings op die gebied van die sosiologiese wetenskappe self, wat poog om sommige van die metodologiese swakhede van die verlede uit te skakel en so nuwe gebruiksmoontlikhede open.

Die belangrikste aanleiding tot die hernude belangstelling is egter 'n bewuswording van die preokkupasie van heersende eksegetiese metodes met die literêre en historiese aspekte van tekste. Sonder om noodwendig die potensiële waarde en bydrae van daardie metodes te ontken, word byvoorbeeld beweer dat hierdie oorbeklemtoning van literêr-historiese en teologiese kwaliteite van tekste gelei het tot die negering of onderwaardering van hul sosiologiese aard 20 . Hiermee hang saam 'n ongenoeë met die ongeïntegreerdheid van die resultate van Bybelnavorsing en die kompartementalisasie van kennis ${ }^{21}$. Dit alles het daartoe gelei dat daar in reaksie hierop tans 'n beduidende aantal werkwyses is wat vanuit 'n sosiologiese perspektief opereer.

Die verskillende werkwyses kan in twee verbandhoudende kategorieë verdeel word, naamlik (1) 'n beskrywende en (2) 'n verklarende.

(1) Die eerste kategorie mik slegs op die versameling en beskrywing van sosiale feite. Hieronder tel onder andere die beskrywing van sosiale realia soos die manier van nedersetting en gebruiksartikels ${ }^{22}$, die sosiale gebruike en samestelling van groepe, sosiale en politieke instellings ${ }^{23}$, asook sosiale geskiedenisse van spesifieke groepe of tydperke 24 . Dit is 'n voortsetting, maar ook uitbreiding van die tradisionele gebruik van sosiale data.

(2) Die tweede kategorie werkwyses maak gebruik van die resultate van die eerste, maar poog om die innerlike, onderliggende dinamiek van die sosiale feite met behulp van ' $n$ teorie of 'n model te verklaar 25 . Die keuse van die model of teorie hang saam met die besondere en eie aard van die vraagstelling of objek onder beskouing, asook van die tipe inligting wat verlang word. Elke model of teorie is vraagspesifiek of area-spesifiek; geen enkele model is universeel bruikbaar nie.

Voorbeelde van sake wat sosiologies ondersoek kan word, is onder andere 'n samelewing se sosiale organisasie in terme van die sosiale kragte werksaam en die betrokke sosiale instellings; groepsdinamiek van byvoorbeeld 'n kultus, 'n sekte of 'n klas; groepsinteraksie; konflik; mense se selfverstaan; hul reaksie op ontnugtering; hul norme, simboliese sisteme en sosiaal gekonstrueerde betekeniswêrelde; sosiale aspekte van 'n spesifieke teks; asook die sosiologie van literatuur in die algemeen. Modelle en teorieë wat gebruik kan word, sluit in makro- en mikro-sosiologiese samelewingsteorieë, antropologiese teorieë, sosiale-sielkundeteorieë, rolanalise, kognitiewe dissonansie en kennissosiologie 26 .

Omdat die Ou-Testamentiese tekste egter nie sosiologies bedoel was nie, 
kan die sosiologiese modelle nie direk op die tekste toegepas word nie. Die saak wat ondersoek moet word, moet dus eers met behulp van die tekste gekonstrueer word op so 'n wyse dat sosiologies interpreteerbare data uitgelig en beskikbaar gestel word, en daarna kan die sosiologiese verklaring volg. Die wyse waarop die konstruksie gedoen sal word, hang nou saam met die aard van die saak waarop gefokus word. Die klem kan soms meer literêr wees, wat sal meebring dat die teksarbeid op literêre aspekte sal fokus, of soms meer histories, wat sal meebring dat die teksarbeid meer op die vlak van historiese konstruksie sal fokus.

Soos met enige ander werkwyse, het kritiek nie uitgebly nie 27 . 'n Verantwoordelike, ingeligte gebruik van 'n sosiologiese verwysingsraamwerk kan egter baie nuttig wees.

\section{$2.2 \quad$ Sosiologiese teksanalise - 'n oorsig}

Sosiologiese teksanalise maak gebruik van sosiologiese modelle om 'n teks as produk van 'n spesifieke sosiale werklikheid te verstaan 28 . Die teks is die vertrekpunt en kontrole van die sosiologiese analise ${ }^{29}$. Dit verskil van sosiologiese ondersoeke wat tot dusver meer gefokus het op sosiologiese kenmerke, prosesse en ontwikkelings van spesifieke tydperke of samelewings, waarmee eksegetiese resultate vergelyk is en waar die teks 'n ondersteunende rol speel. Elliot ${ }^{30}$ definieer sosiologiese teksanalise as die analitiese en sintetiese interpretasie van 'n teks deur die gesamentlike gebruik van eksegetiese en sosiologiese dissiplines, hul beginsels, teorieë en tegnieke. Dit is sosiologies omdat dit gebruik maak van die perspektiewe, veronderstellings, werkwyses, vergelykende modelle, teorieë en navorsing van die sosiologie. Dit is eksegeties omdat dit op 'n teks fokus en gebruik maak van al die subdissiplines van eksegese om die betekenis en impak van die teks in sy verskeie kontekste te bepaal.

Elliot ${ }^{31}$ noem verskeie sosiologiese aspekte van tekste:

- die verklaring van hoe en hoekom 'n spesifieke situasie tot die teks aanleiding gegee het;

- die bedoelde sosio-religieuse funksie wat dit moes uitgeoefen het;

- die bedoelde en werklike impak daarvan op die lewe en handeling van die ontvangers en formuleerders; en

- die spesifieke invloed van sosiale behoeftes, sosiale konflik, groepsbelange en botsende ideologieë op idees en denke.

Al hierdie aspekte kan onder die noemer van 'n Bybelse literatuursosiologie ingepas word, en geskied aan die hand van sosiologiese modelle en teorieë.

Volgens Elliot ${ }^{32}$ is dit nodig om bewus te wees van die voorveronderstellings waarop hierdie aanpak berus. Die eerste hiervan is die aanname dat Bybelse dokumente en tradisies die produkte asook kanale van sosiale interaksie is. Daarom moet daar aandag gegee word aan die interpersoonlike of sosiale transaksies en verhoudings waarna ' $n$ teks implisiet of eksplisiet verwys. 'n Verdere aanname komende vanuit die kennissosiologie is dat perspektiewe sosiaal bepaald is, met ander woorde dat hulle in 'n wisselwerkende verhouding staan met die sosiale ervaring, klas en status, optrede en belange van die formuleerders daarvan. Daar is ook 'n korrelasie tussen situasie en strategie, waar situasie verwys na die 
tipiese velde van sosiale interaksie wat die teks gevorm het, en strategie na die doelbewuste opbou van 'n teks om 'n bedoelde effek op die gekose gehoor te he. 'n Teks word dus gesien as 'n reaksie op 'n gegewe situasie en is bedoel om 'n spesifieke reaksie uit te lok. Hierby kan gevoeg word dat sosiologiese teksanalise belang stel in die mate waarin die teks die sosiale belange, klasposisies, organisatoriese strukture, geografiese posisie en wyses waarop gesag uitgeoefen word, weerspieël. Die teks reflekteer ook 'n simboliese universum (die integrasie van godsdienstige sienings, tradisies, waardes en doelwitte) en vervul 'n spesifieke funksie ten opsigte daarvan. Laastens wys Elliot daarop dat die eksegeet self tyd- en oordgebonde is.

Dit blyk dus moontlik te wees om 'n sosiologiese interesse spesifiek op 'n teks te rig en daardeur te laat lei.

Die probleem waarop Klaagliedere reageer het was die verlies van bakens. Die vraag is egter - wat was die posisie en doel van die outeurs? Was hulle mense wat die ramp sien kom het, en nou vir die volk oproep om hulle te bekeer van hul misplaaste vertroue op onbetroubare bakens? Het hulle dalk eers self geglo dat die belofte van die land, die stad en die koning onvoorwaardelike ankers vir 'n veilige voortbestaan is, maar is toe deur die ramp van hul fout oortuig? Is daar genoeg inligting in die liedere om hieroor antwoorde te gee?

Die probleem is dus die sosiale affiliasie van outeurs. Omdat daar in die boek self geen inligting oor hulle is nie, moet dit uit die argumentstruktuur afgelei word, en wel in vergelyking met die argumentstrukture van ander Ou-Testamentiese boeke. Dít, gesien teen die agtergrond van die sosiale funksie van geloof in Israel, kan vir 'n mens 'n aanduiding gee van die sosiale plasing, en daarmee saam die doel van die liedere.

\subsection{Die outeurs van Klaagliedere}

Die outeurs van Klaagliedere was Sionsteoloë vir wie die gebeure van 586 vC heeltemal onverwags, selfs ondenkbaar, was ${ }^{33}$. Soos die meeste ander Israeliete is hulle deur gebeure vóór die val oortuig dat God se beloftes rakende land, stad en koning onvoorwaardelik en ewigdurend is. Jerusalem is in dié tyd telkemale wonderbaarlik gespaar ${ }^{34}$ :

- tydens die Siro-Efraïmitiese oorlog van 734-732 vC;

- in 722 vC toe Salmanasser nie die stad kon inneem nie;

- in $701 \mathrm{vC}$, toe Sanherib 'n aanval op die stad geloods het;

- in $609 \mathrm{vC}$, toe farao Nego onverwags sy beleg van Jerusalem opgesê het;

- in $597 \mathrm{vC}$, toe Jerusalem die eerste beleg van Nebukadneser oorleef het, en

- in 588, toe die stad op 'n kritieke tyd deur Egiptiese hulptroepe ontset is.

Dieselfde geld vir hul vertroue op die Dawidiese koningshuis.

- In 734-732 vC kon Resin en Peka nie daarin slaag om Agas die dawidied deur een van hul handlangers te vervang nie; 
- in 701 het Hiskia bly heers, terwyl talle ander konings wat aan die opstand deel gehad het, afgesit is;

- in $639 \mathrm{vC}$ het sekere mense wat verwant was aan die dawidiese linie steeds die hef in die hand gehad, selfs na die moord op Amon;

- na die oorwinning oor Josia in 609 vC plaas farao Nego vir Eljakim, uit die huis van Dawid, as regent op die troon; en

- in 597 vC vervang Nebukadneser vir Jojakin met 'n ander dawidied, naamlik Mattanja.

Hierdie herhaaldelike bevestiging van die beloftes rakende die land, stad en koning het dus die geloof daarin versterk, tot so 'n mate dat enige nuwe bedreiging nie ernstig bejeën is nie, en dat enige waarskuwing oor verkeerde optrede en moontlike straf geïgnoreer is. In die lig hiervan is dit verstaanbaar dat die verlies van die land, stad en koning nie net totaal onverwags was nie, maar dat die mense dit beleef het as die totale vernietiging van hul geloofsankers.

\section{Die ontstaan van die bundel}

Die digters wou hierdie probleem oplos. Waarskynlik het die ontstaansproses van die bundel liedere soos volg verloop. Een persoon, verbonde aan die kultus in Jerusalem, het 'n lied oor die ramp en sy gevolge gedig - moontlik Klaagliedere 2. Die gebruik van die akrostiese vorm om dit te doen, het 'n beweging op tou gesit vir die skryf van verdere liedere op dieselfde patroon. Hieraan het verskillende persone beplan en die liedere gedig en saamgevoeg om die boek Klaagliedere te vorm. Die doel hiervan was om die probleme en vrae wat in hul eie en die volk se harte geleef het, aan te spreek en 'n antwoord daarop te bied. Terselfdertyd is dit waarskynlik gedig om tydens godsdienstige samekomste voorgedra te word. Só kon die idees daarin vervat aan die gelowiges oorgedra word, en is die geloof van die geskokte gelowiges weer op vaste fondamente geplaas - hul smart is aangespreek, en die kultus het voortgegaan, al was dit in 'n ander gestalte as vroeër.

Die doel van die digters kan soos volg beskryf word: Die digters van Klaagliedere wou die godsdienstige puinhoop wat deur die val van Jerusalem agtergelaat is, opruim en die fondamente van die geloof oopkrap en skoonmaak. Die digters het dus ten doel gehad om die hoorders se geloofsprobleme, geskep deur die gebeure in die verlede, te hanteer. Daarom gee hulle in die verskillende liedere (hoofstukke) onderrig vir die hede en hoop vir die toekoms. Hulle poog dit deur die verskillende hoofstukke soos volg te rangskik:

1 Verlede: beskrywing van chaos en bede om herstel

2 Verlede: wanhoop as gevolg van kansellering van verkiesing

3 Hede: onderrig - hoop op die Here

4 Toekoms: wanhoop oorwin en nuwe hoop

5 Toekoms: beskrywing van bestaansnood en bede om herstel

Die wanhoop waarin die mense verkeer as gevolg van die verlies van hul bakens, word opgelos deur hulle 'n nuwe anker te bied. Waar hulle tot nog toe hulleself aan stad, land en koning georiënteer het, leer (onderrig) die skrywers hulle nou om God self hulle anker te maak (hoofstuk 3 ). Die hoofstukke weerskante van die sentrale 
hoofstuk is spesifiek só geplaas om hierdie saak te ondersteun. Die tema van hoofstuk 2 is die wanhoop wat hulle ervaar het toe hulle hul anker, naamlik die uitverkiesing van Israel, verloor het. In plaas van sekerheid en vastigheid, het onsekerheid en ontnugtering die bepalende faktor geword in die lig waarvan die verlede, hede en toekoms beskou is. Die digter beskryf dit in die fynste, selfs grusaamste detail, maar plaas dit in balans met hoofstuk 4. Dié hoofstuk het ook wanhoop as tema, maar in teenstelling met hoofstuk 2 is dit wanhoop oorwin deur nuwe hoop.

Dieselfde geld vir hoofstukke 1 en 5. Die klem in hoofstuk 1 val op die beskrywing van die chaos, met mindere klem op die bede om herstel. Die feit van chaos het die enigste sekerheid geword. Hierteenoor val die klem van hoofstuk 5 op die bede om herstel, met mindere klem op die beskrywing van die chaos. Te midde van die chaos kan mens net hoop dat God'n gebed sal hoor en verhoor. God self word die punt van oriëntasie.

Die digters maak hier gebruik van 'n baie interessante strategie. Twee onversoenbare idees (wanhoop teenoor hoop, chaos teenoor God-in-beheer) word direk naas mekaar gestel. Aangesien dit onversoenbare teenoorgesteldes is, kan dit nie saam funksioneer nie. Die gevolg is dat die hoorders uit hul denkgroewe uitgedwing word, en dus oop is om alternatiewe te oorweeg. Hoofstuk 3 doen dan'n alternatief aan die hand, deur te sê dat hulle God hul baken moet maak. Hierdie selfde strategie is ook in die verskillende liedere teenwoordig. Hoofstuk 3 dien as voorbeeld.

Klaagliedere 3

\subsubsection{Opbou}

Dit is nie maklik om die gedagtegang van Klaagliedere 3 te volg nie. Sommige verklaarders beskou dit as die gevolg van die vorm waarin die lied gegiet is. Klaagliedere 3 is, soos die ander liedere, ook 'n akrostiese lied waar elke strofe met ' $n$ volgende letter van die alfabet begin. Die lied verskil egter van die ander in dié sin dat al drie reëls van elke strofe telkens met die betrokke letter begin. Hierdie geweldige streng vorm sou dan volgens hulle 'n keurslyf gewees het wat die digter beperk het. Ander verklaarders 35 het egter ten spyte van die streng ordening wel 'n baie fyn struktuur, ooreenstemmend met dié van die hoofstukke van die boek self, in die lied raaksgesien. Dit kan só voorgestel word:
$1-16$ berig van 'n enkeling
17-20 klag van'n enkeling
21-24 oproep tot vertroue
25-33 onderrig
34-39 onderrig
40-47 oproep tot bekering
48-51 klag van 'n enkeling
$52-66$ berig van 'n enkeling

Verse 1-16 vorm 'n eenheid waarin die digter die nood beskryf waarin hy hom bevind. ' $n$ Individu ("ek") kom in vers 1 aan die woord, wat vanaf vers 2 tot 16 vertel 
dat hy die objek van handeling deur 'n ongeïdentifiscerde persoon is. Hierdie persoon word in vers 17 direk aangespreek, en eers uit vers 18 is dit indirek af te lei dat die persoon Jahwe is. Vanaf vers 17 wend die digter hom direk tot Jahwe. Dit is nie meer 'n beskrywing soos die vorige sestien verse nie, maar 'n beoordeling van dit wat ervaar is. Verse $21-24$ is 'n oproep tot vertroue. Die eerste vier en twintig verse bevat dus 'n beskrywing van 'n sinsbevraagtekenende ervaring, nadenke daaroor en 'n oplossing daarvoor.

Verse $25-39$ is onderwysend van aard. Dit is opgebou uit drie waarspreuke (25-27), drie vermanings- of raadgewende spreuke (28-30) en drie verdere waarspreuke (31-33). Verse 31-33 is nie net 'n begronding van verse $25-30$ nie, maar ook van verse 1-24. Verse 34-39 is steeds in die derde persoon enkelvoud, maar is in teenstelling met die styl van die direk voorafgaande verse in die vorm van retoriese vrae. Die gedeelte is 'n konkretisering van die algemeen geldige waarhede in verse 25-33 vir 'n spesifieke situasie, naamlik die tyd na die katastrofe van $586 \mathrm{vC}$.

Verse $40-47$ is in die eerste persoon meervoud. Dit is 'n boetelied met 'n onderwysende doel, wat logies op die woord $\mathrm{KD}$ (sonde) in vers 39 volg.

In vers 48 is daar weer 'n subjekwisseling. Verse $48-66$ is, soos $1-24$, in die eerste persoon enkelvoud. Verse 48-51 is 'n kort individuele klaaglied (soos 17-20) oor die verbreking (שכר in 47 en 48). Verse 52-54 is die skildering van die nood, en verse 55-57 vertel van die hulpgeroep en Jahwe se antwoord daarop. Verse 58-61 antwoord op die bevraagtekening van Jahwe se soewereiniteit in verse 34-39

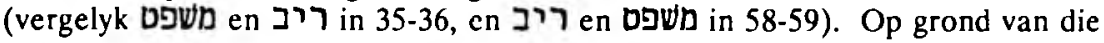
digter se ervaring in die verlede, volg in verse $62-66$ 'n bede om hulp vir die steeds voortdurende lyding. Die doel van die gedeelte is om die hoorders te onderrig aan die hand van die voorbeeld van die digter.

Hieruit blyk dat die nood wat die digter ervaar en verwoord nie lyding as sodanig is nie, maar die ervaring dat God onbereikbaar ver voel omdat Hy toornig is en oordeel. Die lied is dus nie ' $n$ individuele klaaglied oor persoonlike lyding nie, maar spreek eerder die probleem aan van hoe om te bly glo en hoe om op te tree tydens die ervaring van lyding.

\subsubsection{Argumentstruktuur}

Die doel van die digter was om sy hoorders te onderrig. Daarom is dit belangrik om sy argumentstruktuur raak te sien. Die digter het probleemvrae waarmee die volk geworstel het, raakgesien en aangespreek. Die vraagstukke is veroorsaak deur die lyding wat die Israeliete ná die katastrofe van $586 \mathrm{vC}$ beleef het. Daarom begin die digter met ' $n$ "berig" van leed (1-16) wat hy self ervaar het as voorbeeld van die algemene leed van sy tydgenote, gevolg deur'n klag daaroor (17-20). Hy deel egter ook mee wat hy as oplossing daarvoor ervaar het (21-24). Hieruit lei hy algemeen geldende waarhede af, en pas dit toe op die spesifieke situasie en vrae van sy hoorders (25-39). Vir hulle impliseer dit dat hulle hul moet bekeer (40-47) en dat hulle by die Here om hulp moet aandring (48-51), omdat die ervaring bewys dat die Here se hulp sonder twyfel sal realiseer (52-66).

Alhoewel die vraagstukke veroorsaak is deur die lyding wat hul moes deurmaak, blyk dit uit die lied dat die basiese probleem waarmee die gemeenskap worstel nie die lyding as sodanig is nie, maar wel die ervaring dat hulle volgens hulleself 'n onverdiende lot ervaar het (vergelyk Geertz se siening oor die funksie 
van geloof, punt 4). Dit blyk veral uit verse 1-20, asook verse 34-36. Die lydende (as verteenwoordiger van alle tydgenootlike lydendes) beskou homself as 'n godvrugtige gelowige wat doen wat God verlang, maar ellende in plaas van seën ervaar. Die oorsaak van hul lyding is dus die vreemde optrede van God. In plaas daarvan dat God hom met sy herderstaf beskerm, hom na die goeie lei en hom met die mag tot sy beskikking ondersteun, slaan God hom met die staf, lei Hy hom na die sfeer van die onheil en gebruik Hy sy mag tot die gelowige se nadeel (verse 1-3). Waar die godvrugtige gelowige op grond van vertrouensuitsprake soos Psalm 37:2324 kon verwag dat God hom op die lewenspad sou help, ervaar hy God as die een wat sy pad onbegaanbaar en lewensgevaarlik maak (verse 9-11). Waar hy lewensonderhoud en 'n veilige onderdak van God, die groot Gasheer, verwag het, ervaar hy lewensbedreigende behandeling (verse 15-16). Waar hy gehoop het op God se reddende verskyning (vers 18 ), ervaar hy wanhoop en vertwyfeling (verse 19 20). Dit alles laat hom daaraan twyfel of God nog volgens sy eie orde optree. Hoekom laat die Allerhoogste Wêreldregter toe dat die mense wat gewoonlik op sy beskerming kan staatmaak (verse 34-36), onreg verduur? Die onverwagsheid van hul lot spreek duidelik hieruit.

Die agtergrond van hul verwagtings is die daad-gevolg-samehang soos onder andere bekend uit die wysheidsgeskrifte. Hiervolgens het goeie dade seën ten gevolg, en slegte dade straf. Aangesien hulle hulself beskou het as regverdiges wat die goeie doen (vergelyk "regverdige" of "man" in verse 1 en 35), is hulle lot vir hulle onverstaanbaar en in stryd met die lewensverordeninge soos wat hulle dit verstaan het. Hulle betwyfel dus nie die bestaan van die ordebeginsel nie. Inteendeel, hulle uitsprake veronderstel dit. Hulle kla wel omdat die orde nie gehandhaaf word soos die beginsel vereis nie. So bevraagteken hulle God se mag om te kan help (verse 17-18) asook die logiese grond agter en regverdigheid van God se optrede (verse 34-36).

Hierop reageer die digter ook in wysheidsterme. Daar is reeds in die voorafgaande analise gewys op die digter se deurlopende gebruik van wysheidstyl en -tegnieke. Soos hieruit verwag kan word, is sy denke ook wysheidsgeoriënteerd. Tog, ten spyte van hulle gemeenskaplike agtergrond, verskil die digter se konklusie van dié van sy tydgenote, en wel omdat hy ander aspekte beklemtoon as hulle.

Waar sy tydgenote hul aandag op hul "onregverdige" lot gefikseer het, daaruit afgelei het dat God ontrou aan Homself geword het en deur te kla 'n regstelling daarvan geëis het, fokus die digter op die wese van God. Daarom begin die digter sy beklemtoning met die uitspraak dat God se goedgunstigheid en barmhartigheid eindeloos is (vs 22). Nie hul huidige lot nie, maar die ewige, basiese wesenskenmerke van God behoort volgens hom die vertrekpunt te wees. Op grond van hierdie konstantheid in die wese van God kan hulle glo dat sy heilstoeseggings steeds van krag is. Die konstantheid van God se onuitputlike verbondstrou word vergelyk met die reëlmaat waarmee een dag op die ander volg (vers 23). Die Here is steeds getrou, en kan dus met reg as die basis van hulle eksistensie op wie hulle met sekerheid kan hoop, bestempel word (vers 24).

Dit word bevestig wanneer mens die houding en optrede wat die digter vir sy hoorders aanbeveel, beskou. Op grond van sy siening van God, raai hy sy hoorders aan om alles aan God oor te laat en hulle lot te aanvaar soos dit is (verse 25-30). God se goedheid geld vir diegene wat op Hom wag, met ander woorde daardie gelowiges wat deur hulle optrede blyke gee van die innerlike oortuiging dat 
God steeds in staat en bereid is om te help. As motivering argumenteer die digter soos volg. Volgens hom is die Here se oordeel van beperkte duur, maar sy toegeneentheid en medelye ewigdurend (verse 31-32).

Met hierdie beklemtoning van God en sy basiese ingesteldheid teenoor die mens het die digter sy tydgenote se eerste probleem, hulle twyfel aan God se mag om te kan help, gehanteer. Dit laat egter nog die tweede probleem, naamlik die vraag of daar ' $n$ bevredigende rasionaal agter sy optrede is, onbeantwoord. Hierdie vraag kom implisiet in vers 33 na vore wanneer die digter sê dat God nie goedsmoeds verdruk nie. Waarom dan wel? sou mens wou vra. Hy weet die vraag leef in sy godvresende hoorders (2ר vers 35 ) se harte (verse 34-36), en daarom antwoord die digter daarop vanaf vers 37 .

Die digter begin deur te beklemtoon dat God die Skepper is (vers 37). In die wysheidsliteratuur funksioneer die skeppingsmotief as 'n simbool van orde, nie primêr as 'n verwysing na die oorspronge van die aarde nie. God het met die skepping die kosmiese orde daargestel, en Hy self sien om na die voortbestaan van die geordende werklikheid. Omdat die ballingskap die historiese basis van die Israelitiese geloof bevraagteken het, is die horison van die geskiedenis verbreed. Die eertydse volkshistoriese beskouing is vervang deur 'n wêreldhistoriese beskouing waarin die skeppingsdade van God beklemtoon is. Die doel hiervan was om te beklemtoon dat God nie misluk het nie, maar dat Hy steeds in beheer is. Hierdie verruiming in hul beskouings het dit moontlik gemaak dat die Israeliete later kon glo dat die Here selfs deur'n heidense wêreldheerser soos Kores regeer, en dat die nuwe heilstyd aangebreek het selfs al was hulle as volk steeds onder vreemde heerskappy.

Hulle kon dus glo dat God steeds in beheer is selfs wanneer gelowiges van die verbondsvolk ly (vers 38 ). Die digter volstaan egter nie met die blote uitspraak dat God se optrede as ordelik bestempel kan word nie. Hy verskaf ook 'n rede waarom hulle lyding ervaar - die mens, selfs die godvresende, is sondig (vers 39). Die sonde was die oorsaak vir God se toorn (verse 42-47). God het dus 'n baie goeie rede gehad om op te tree soos wat Hy gedoen het. God is nie 'n blinde demoon wat die kwaad uitdeel sonder aansiens des persoons nie. Die sondemotief funksioneer dus as 'n verklaringsbeginsel. Hul sonde was die rede vir God se optrede, en die oplossing hiervoor is om hulle opnuut en opreg van Hom afhanklik te stel.

Dit het egter nie gelei tot 'n oproep om groter etiese verantwoordelikheid te aanvaar nie. Volgens hulle wêreldbeeld skep God die orde, en die mens moet dit aanvaar en daarby inskakel. Die mens is nie daartoe in staat om self 'n bydrae tot sy heil te lewer nie. Die mens behoort net daartoe in staat te wees om die Here se optrede te kan raaksien. Só het die beklemtoning ontstaan van God wat die heil ten spyte van menslike skuld verwerklik.

Hiermee help die digters die lesers en hoorders om die negatiewe bril waarmee hulle na die verlede kyk met' $n$ ander te vervang. Hulle lot was volgens hulle siening onverdiend: 'n onregverdige God het nie volgens die reëls van die daad-gevolg-samehang gespeel nie. Dit het hulle laat vermoed dat hy selfs onmagtig is, en nie is staat om hulle te help nie. So 'n siening het uiteraard ' $n$ vernietigende gevolg vir hulle toekomsverwagting gehad.

Die digter help hulle egter om dié las af te gooi. Hy gebruik ook die beginsels van die daad-gevolg-samehang, maar omdat hy hom deur ander 
swaartepunte laat lei, is sy konklusie anders as hulle s'n. Nie hul lyding en lot nie, maar God se wese en ewige trou dra die klem. Daarom kan en sal hy steeds help, en is die toekoms nie so duister nie.

Die digter vervang egter nie net die hoorders se negatiewe bril nie. Hy gee hul ook 'n bril met 'n ander fokuspunt. Hyself en die hoorders het eers op hul eie geskiedenis gepeil. Na die katastrofe is dit egter nie meer moontlik nie. Daarom kyk hulle daarby verby, en fokus eerder op die wêreldgeskiedenis en skepping. Indien mens na bakens soek om aan te anker, is God se skeppingsordeninge baie meer sigbaar as hul eie geskiedenis.

Die digter en die hoorders se verlede bly dus dieselfde, maar hul beskouings en gevoelens daaroor het verander.

Vir die digter en sy tydgenote was die heil nog nie 'n werklikheid nie, aangesien hulle steeds lyding ervaar het. Wat staan hulle in die lig hiervan te doen? Getrou aan hul wêreldbeeld beveel die digter sy hoorders aan om nie die heil self te probeer verwerklik nie. Volgens vers 50 kla die digter, nie om die Here aan te kla nie, maar om Hom tot ingrype te beweeg (vergelyk vss 41 en 50). Hieropvolgend funksioneer die berig van verse 52-66 as 'n aanduiding dat so' 'n houding nie 'n leë hoop is nie, maar dat dit in die verlede al vrug afgewerp het. Daarom kan daar ook vas geglo word dat God die onreg wat die vyande teen hulle gepleeg het, sal vergeld (vergelyk vs 66 met vss 41 en 50), net soos Hy die onreg wat hulle self gepleeg het, vergeld het. Hulle kon dus by wyse van spreke 'n mentale kleedrepetisie deurgaan, en só die toekoms met moed tegemoetstap.

Hiermee het die digter sy doel bereik. Hy het aangetoon dat God steeds getrou is en steeds in staat is om te help. Hy het ook aangetoon dat God nie 'n fout gemaak het toe Hy hulle lyding laat smaak het nie - inteendeel, God het heeltemal in ooreenstemming met die ordening van die werklikheid opgetree. Dit is die basis waarop hoop vir die toekoms gebou kan word. God sal ook diegene wat teenoor hulle oortree het straf, en só hulle huidige lyding verlig.

Hierdie boodskap word egter verder ondersteun deur die vorm waarin die lied gegiet is. Die hoofstuk waarin die oplossing vir hul probleem aan die hand gedoen word, naamlik hoofstuk 3 , is ook die een waarin die akrostiese vorm die konsekwentste gebruik word. Al drie reëls van elke strofe begin met die betrokke alfabetletter. Die rede hiervoor is dat die digter hiermee wou onderstreep dat God steeds alles ordelik in stand hou. Daarom bespreek hy die chaos ordelik. Vorm en inhoud speel dus dieselfde deuntjie.

Ons is op hierdie stadium in Suid-Afrika in 'n gelyksoortige situasie as die waarop Klaagliedere reageer. Koos du Plessis het dit só geneurie: "...en alles wat eens vas was, vervaag tot blote skadu's teen die muur". Dit geld vir diegene wat voel hulle gaan alles verloor waarop hulle die afgelope paar dekades peil getrek het. Dit kan egter ook geld vir dié met hoë verwagtings van die nuwe bestel. Hoe dit ook al sy, dit kan ons baat indien ons vroegtydig die aard van ons ankers, bakens en meestersimbole krities beskou. Is dit waarop ons om lewe en dood vasklou, regtig onontbeerlik? Is dit waarmee ons dinge wil vervang, werklik 'n verbetering? Hoe lyk ankers wat ons en ander regtig in moeilike waters geborge gaan hou? Die digters van Klaagliedere het ontdek dat beskouings oor God ineen kan tuimel, sonder dat 
God self daarmee heen is. Hulle geloof het uiteindelik wel bygedra tot die verligting van hul eksistensiële angs, maar eers toe hulle van oortollige laste ontslae geraak het. Die geborgenheid wat in God self setel, ook te midde van persoonlike en nasionale lyding, het daartoe gelei dat hulle lokus van kontrole na binne verskuif het. Hulle kon kies hoe hulle oor dinge voel, en was nie meer net aan eksterne impulse uitgelewer nie. God skep steeds aan ons die ruimte om georiënteerd te leef. Of ons egter soos Hansie en Grietjie uit die kloue van die heks gaan ontsnap en selfs 'n pad ("the high road"?) uit die bos gaan kry, gaan daarom afhang van die aard van die bakens wat ons kies, en die mate waarin ons bereid is om self verantwoordelikheid vir ons en ander te aanvaar.

\section{NOTAS:}

1 R A Segal, "The application of symbolic anthropology to religions of the Greco-Roman world", $R S R$ vol 10 (1984), 216-223.

2 C Geertz, "Religion as a cultural system", in The interpretation of cultures. Selected essays, New York 1973; E J Lott, "The science of religion in an Indian theological context", Bangalore Th $F$ vol 17/4 (1985), 1-18; R A Segal, "The 'de-sociologizing' of the sociology of religion", Scottish Journal of Religious Studies vol 7 (1986), 3-28.

3 B J Malina, "The social sciences and biblical interpretation", in The Bible and liberation (edited by N K Gottwald, New York 1983, 11-25); B J Malina, "Why interpret the Bible with the social sciences", $A B Q 2$ (1983), 119-133.

$4 \quad$ Malina $a w, 1983,121-122$.

$5 \quad$ N R Petersen, Rediscovering Paul, Philadelphia 1985.

6 W Brueggemann, "Trajectories in Old Testament literature and the sociology of ancient Israel", JBL vol 98 (1979), 161-185; R P Carroll, "Twilight of prophecy or dawn of apocalyptic?" JSOT vol 14 (1979), 3-35; R Scroggs, "The sociological interpretation of the New Testament: the present state of research" NTS vol 26 (1980), 164-179; J H Elliot, $A$ home for the homeless. London 1981; B O Long, "Social dimensions of prophetic conflict", Semeia vol 21 (1982), 31-53; N K Gottwald, "Sociological method in biblical research and contemporary peace studies", $A B Q$ vol 2 (1983), 142-156; N K Gottwald The Hebrew Bible - a socio-literary introduction. Philadelphia 1985; N K Gottwald, "Social matrix and canonical shape", ThTo vol 42 (1985), 307-321.

N K Gottwald, The tribes of Yahweh, London 1979; P G R de Villiers, "Renaissance van die sosiologiese teksanalise", Th Ev vol 15 (1982), 19-32; D Lockhead. "Ideology and the word: pastoral and theological reflections on sociological criticism of the Bible", $A B Q$ vol 2 (1983), 100-104; W Schottroff \& W Stegemann (eds), God of the lowly. Socio-historical interpretations of the Bible, New York 1984; W von Jüchen, "What a pastor expects from a materialist reading of the Bible: a letter", in W Schottroff \& W Stegemann, $a$ $w, 1984$; K Füssel, "Materialist readings of the Bible: report on an alternative 
approach to biblical texts", in W Schottroff \& W Stegemann, $a w, 1984$.

8 W R Herzog II, "Interpretation as discovery and creation: sociological dimensions of biblical hermeneutics", $A B Q$ vol 2 (1983), 105-118.

$9 \mathrm{~J}$ van Luxemburg, M Bal \& W G Weststeijn, Inleiding in de literatuurwetenschap, Muiderberg ${ }^{3} 1983$.

10 M Maren-Grisebach, Methoden der Literaturwissenschaft, München ${ }^{4} 1976$.

11 Van Luxemburg et al, a w, 115-118.

12 R R Wilson, Sociological approaches to the Old Testament, Philadelphia 1984.

13 J Z Smith, "The social description of early Christianity", RSR vol 1 (1975), 19-25.

14 Wilson, $a w, 15,24$; B W Anderson, "Biblical theology and sociological interpretation", ThTo vol 42 (1985), 292-306; Smith, RSR vol 1 (1975), 19; Gottwald $a$ w, 13; Anderson, ThTo vol 42 (1985), 294.

15 Wilson, $a w, 25$.

16 Gottwald, $a w, 14$.

17 Gottwald, $a w, x v$; Scroggs, NTS vol 26 (1980), 165; Elliot, $a w, 1$.

18 De Villiers, $T h E v$ vol 15 (1982), 20.

19 Wilson, $a$ w, 25-26.

20 Elliot, $a w, 2$; Anderson, ThTo vol 42 (1985), 295; Gottwald, $a w, 1979,21$.

21 Gottwald, $a w, 7$.

22 Smith, RSR vol 1 (1975), 19.

23 Gottwald, $A B Q$ vol 2 (1983), 144; C Osiek, What are they saying about the social setting of the New Testament? New York/Ramsey 1984.

24 Smith, RSR vol 1 (1975), 19-20; Scroggs, NTS vol 26 (1980), 167; C S Rodd, "On applying a sociological theory to biblical studies", JSOT vol 19 (1981), 95106; Gottwald $A B Q$ vol 2 (1983), 144.

25 Osiek, $a w, 4$.

26 Smith, RSR vol 1 (1975), 20-21; Scroggs NTS vol 26 (1980), 167-179; Rodd, JSOT vol 19 (1981), 95; B J Malina, "The social sciences and biblical interpretation", Interp vol 36 (1982), 233-237.

Gottwald, ABQ vol 2 (1983), 143-146; G Theissen, "The sociological interpretation of religious traditions: its methodological problems as exemplified in early christianity", in Gottwald, $a w, 1983,38-60$; Wilson, $a w$, 
12-23; J H le Roux, "Some remarks on sociology and ancient Israel", OTE vol 3 (1985), 12-17; Gottwald, $a w, 1985,25-29$.

27 I G P Gous, Die herkoms van Klaagliedere. Ongepubliseerde D Th tesis, Universiteit van Suid-Afrika, 1988.

28 De Villiers, Th Ev vol 15 (1982), 22.

29 Elliot $a w, 8$; Gottwald, $A B Q$ vol 2 (1983), 145.

$30 \quad$ Elliot $a w, 6-8$.

31 Elliot $a w, 3-4,8$.

32 Elliot $a w, 9-13$.

33 Gous, $a w$, I G P Gous, "Trajectories of tradition in the literature of Israel: Old Testament attempts to understand reality in socio-economic and political context", OTE vol 2/2 (1989), 47-71.

34 J Renkema, Misschien is er hoop...: de theologische vooronderstellingen van het boek Klaagliederen. Franeker, 1983.

35 R Brandscheidt, Gotteszorn und Menschenleid: die Gerichtsklage des Leidenden Gerechten in Klgl 3, Trier 1983 (TTS 41). 